\title{
Effect of bainite volume fraction on mechanical properties of a ferrite-bainite-martensite steel
}

\author{
A. $\operatorname{Karimi}^{1 *}$, S. Kheirandish ${ }^{1,2}$, M. Mahmoudiniya ${ }^{1}$ \\ ${ }^{1}$ School of Metallurgy and Materials Engineering, Iran University of Science \& Technology (IUST), \\ Tehran 16846-13114, Iran \\ ${ }^{2}$ Center of Excellence for Technology of High Strength Materials, Iran University of Science \& Technology (IUST), \\ Tehran 16846-13114, Iran
}

Received 23 April 2016, received in revised form 29 July 2016, accepted 8 August 2016

\begin{abstract}
Nowadays, triple phase ferrite-bainite-martensite steels have found widespread applications in automotive industry. The volume fraction of different phases is the key factor in determining mechanical properties of these steels. This paper investigates the effect of bainite volume fraction on microstructure and mechanical properties of a triple phase steel. Hence, an intercritical annealing treatment at $780^{\circ} \mathrm{C}$ was followed by austempering treatment at $400^{\circ} \mathrm{C}$ for different times. Microstructures were analysed using optical and scanning electron microscopy, and mechanical properties were also investigated by a tensile test. The results showed that the kinetics of austempering treatment had a good adaptation with JMAK equation. It was also found that increment of bainite phase from 0 to 42 vol.\% decreased ultimate tensile strength from 952 to $578 \mathrm{MPa}$, but from 5.7 to 12 vol.\% ductility increased. Results also showed that triple phase steels with 14.9 and 24.5 vol.\% bainite demonstrated three-stage work hardening behaviour while other samples obeyed two-stage work hardening mechanism.
\end{abstract}

Key words: austempering treatment, triple phase steel, work hardening behaviour, mechanical properties

\section{Introduction}

For the weight reduction, safety performance improvement and cost saving, advanced high-strength steels (AHSS) have been used in the automotive industry. Dual phase (DP) steels are a group of AHSS that contain a soft matrix (ferrite) and a higher strength phase martensite $[1,2]$. Ferrite-martensite dual phase steels exhibit attractive properties such as good strength, high work hardening capacity and continuous yielding behaviour. The mechanical properties of the DP steels depend on morphology and the amount of ferrite and martensite phases which are controlled by the annealing temperature and time, the annealing procedure, alloying elements and quenching media conditions [3].

In spite of these attractive mechanical properties, welding of ferrite-martensite dual phase steels is associated with some problems such as local necking phe- nomena in heat affected zone (HAZ) $[4,5]$. So in last decade many studies were held on the substitution of martensite with bainite in these steels which resulted in ferritic-bainitic dual phase (FBDP) steels [6]. But, some results of these studies also show that ferritebainite dual phase steels do not demonstrate continuous yielding behaviour [7]. It seems that the presence of bainite, as the third phase, in ferrite-martensite dual phase steels might result in a good combination of strength and ductility. So recently a new group of AHSS steels with triple phase microstructure, ferritebainite-martensite, was developed [8].

Generally, the addition of an austempering step at the end of heat treatment cycles used for the production of ferrite-martensite dual phase can result in the production of the triple ferrite-bainite-martensite microstructure. Zare et al. [9] used such heat treatment cycle to an AISI 4340 steel to produce mixed ferrite-bainite-martensite microstructure.

\footnotetext{
*Corresponding author: tel.:+98 9124612963; e-mail address: abolfazl.krm@gmail.com
} 
Table 1. Chemical composition (wt.\%) of investigated steel

\begin{tabular}{cccccc}
\hline $\mathrm{Fe}$ & $\mathrm{C}$ & $\mathrm{Mn}$ & $\mathrm{Si}$ & $\mathrm{P}$ & $\mathrm{S}$ \\
\hline base & 0.166 & 1.35 & 0.22 & 0.006 & 0.003 \\
\hline
\end{tabular}

They achieved a good combination of strength and ductility. Abdollahzade et al. [10] produced triple ferrite-bainite-martensite microstructure by using the step-quenching procedure in a CrMo steel. Although, some research $[9,10]$ has been done on steels with mixed ferrite-bainite-martensite microstructure, but some microstructural and mechanical aspects have not been paying attention in these studies such as (a) kinetic of the bainite transformation during production of a mixed ferrite-bainite-martensite microstructure using an isothermal austempering treatment; (b) work hardening behaviour of triple phase steels. It should also be noted that chemical composition of steel has the main effect on the role of bainite, as the third phase, and on mechanical properties of ferrite-martensite dual phase steels. Accordingly, the aim of the present work is the study of microstructural and mechanical aspects of isothermal bainite transformation in Fe-0.16C-1.35Mn-0.22wt.\%Si steel.

\section{Experimental}

The chemical composition of the material used in this study is given in Table 1 . The investigated steel was available in the form of $3 \mathrm{~mm}$ thick sheet. The initial microstructure of steel was a mixture of ferrite and pearlite. For the intercritical annealing, all specimens were treated for $15 \mathrm{~min}$ at $780^{\circ} \mathrm{C}$. The $A_{\mathrm{c} 1}$ and $A_{\mathrm{c} 3}$ temperatures were calculated to be 720 and $870^{\circ} \mathrm{C}$, respectively, by Eqs. (1) and (2) [11]:

$$
\begin{aligned}
A_{\mathrm{c} 1}\left({ }^{\circ} \mathrm{C}\right)= & 751-16.3 \mathrm{C}-27.5 \mathrm{Mn}-5.5 \mathrm{Cu}-5.9 \mathrm{Ni}+ \\
& +34.9 \mathrm{Si}+12.7 \mathrm{Cr}+3.4 \mathrm{Mo}, \\
A_{\mathrm{c} 3}\left({ }^{\circ} \mathrm{C}\right)= & 881-206 \mathrm{C}-15 \mathrm{Mn}-26.5 \mathrm{Cu}-20.1 \mathrm{Ni}+ \\
& +53.1 \mathrm{Si}+0.7 \mathrm{Cr}+41.7 \mathrm{~V} .
\end{aligned}
$$

Partial austenitized samples were austempered at $400{ }^{\circ} \mathrm{C}$ in $50 \%$ NaNO3 $+50 \% \mathrm{KNO}_{3}$ salt bath for $0,20,45,100,300$, and $900 \mathrm{~s}$, followed by water quenching. The heat treatment cycle is shown in Fig. 1. The dimensions of heat treated specimens were $0.3 \times 2 \times 20 \mathrm{~cm}^{3}$. Temperature measurements were carried out using a k-type thermocouple embedded on the surface of samples. For metallographic preparation, specimens were ground and finally polished by using $0.3 \mu \mathrm{m} \mathrm{Al}{ }_{2} \mathrm{O}_{3}$ powders. Three different etchants were used for microstructural analysis: (1) $2 \%$ nital

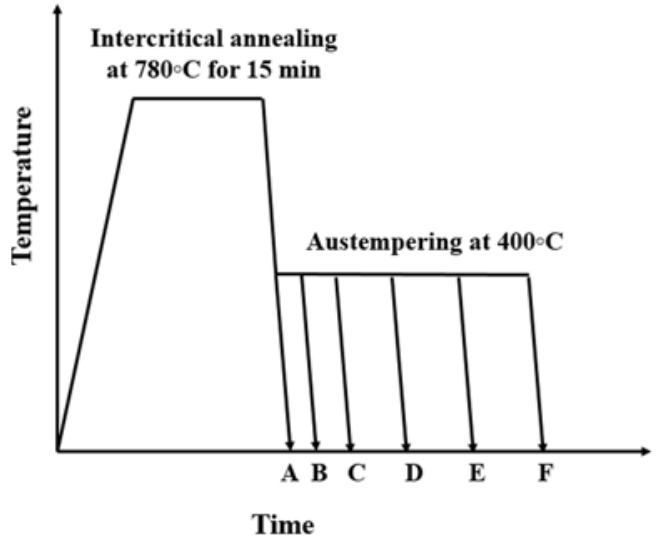

Fig. 1. Schematic of heat treatment cycle used in current study.

solution: ferrite phase appears in bright colour while both of martensite and bainite phases reveal in black colour; (2) Tint etchant (10 g Na $\left.\mathrm{N}_{2} \mathrm{O}_{5}+90 \mathrm{ml} \mathrm{H}_{2} \mathrm{O}\right)$ : the ferrite, martensite, and bainite appear in bright, brown, and blue, respectively [12]; (3) Chromate alkaline: this etchant reveals new ferrite as white, old ferrite as brown, and hard phase (martensite + bainite) in black colour [13]. Analysis of microstructures was carried out using optical and scanning electron microscope operated at $30 \mathrm{kV}$. The volume fractions of phases were measured by clemex vision image analyser software. The tensile test was used to evaluate the mechanical properties. Tensile test specimens were machined according to ASTM E-8 [14], and tests were conducted at room temperature with $100 \mathrm{kN}$ Instron universal testing machine.

\section{Results and discussion}

\subsection{Microstructure}

Figure 2a shows the SEM micrograph of the steel after intercritical annealing at $780^{\circ} \mathrm{C}$ for $15 \mathrm{~min}$, followed by quenching. It is observed that intercritical annealing treatment of the specimen resulted in a martensite network (light regions) surrounding the ferrite grains (dark regions). Actually, when the sample is annealed in $\alpha+\gamma$ region, austenite grains are nucleated at the carbide/ferrite interfaces and grow, and they transform to the martensite after water quenching [3]. Firstly, the pearlite decomposes, and a carbonrich austenite phase is formed. This step takes place very quickly. Increasing annealing time causes the increment of the volume fraction of austenite. This phenomenon occurs by growth of austenite phase into the surrounding ferrite [3]. Figure $2 \mathrm{~b}$ shows the microstructure of quenched sample etched with chromate alkaline etchant. It should be mentioned that ferrite 
Table 2. Volume percentage of constituent phases for different austempering times

\begin{tabular}{ccccc}
\hline Austempering time (s) & Old ferrite (vol.\%) & New ferrite (vol.\%) & Martensite (vol.\%) & Bainite (vol.\%) \\
\hline 0 & 36.1 & 16.4 & 47.5 & 0 \\
20 & 31.9 & 24.1 & 37.1 & 6.9 \\
45 & 32.8 & 24.6 & 27.7 & 14.9 \\
100 & 33.7 & 25 & 16.8 & 24.5 \\
300 & 34 & 24.1 & 4.6 & 37.3 \\
900 & 32.9 & 24.4 & 0.5 & 42.2 \\
\hline
\end{tabular}
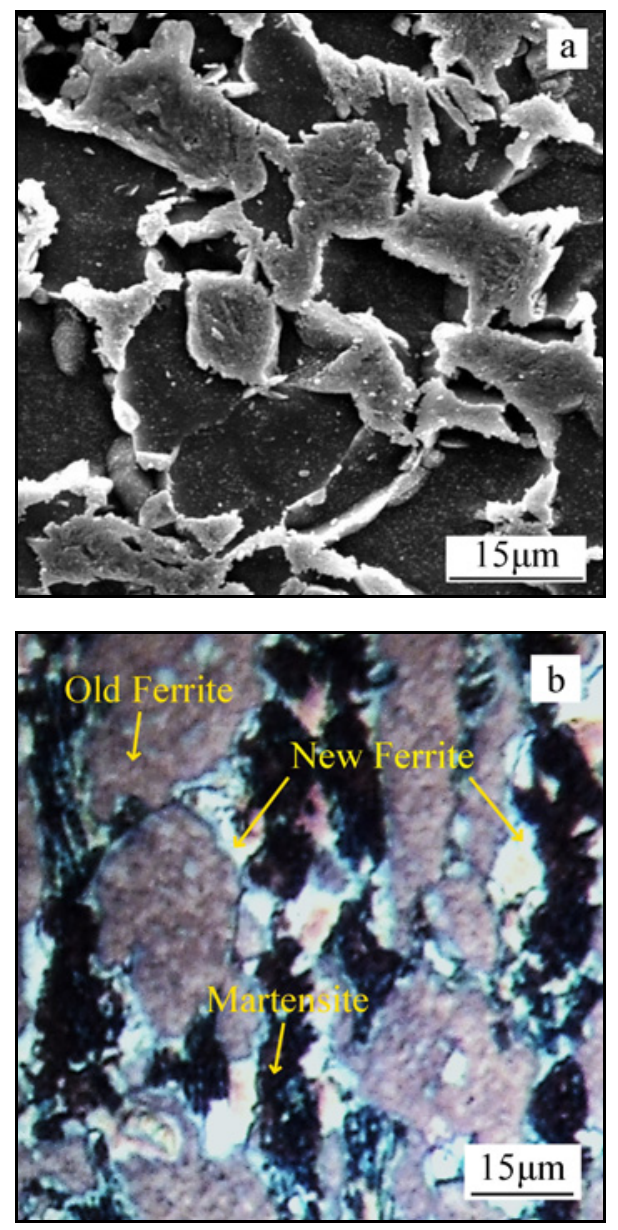

Fig. 2. The microstructure of the steel after intercritical annealing at $780^{\circ} \mathrm{C}$ for $15 \mathrm{~min}$ and followed by quenching: (a) SEM micrograph, (b) optical micrograph, etched with Lawson.

phase can exist in two forms of old and new ferrite (epitaxial ferrite) in the microstructure of dual phase and triple phase steels. New ferrite is the phase that grows after intercritical annealing and differs from the old ferrite that exists at intercritical annealing step [15]. Distinguishing between old and new ferrite cannot be detected easily, but can be discerned using chromate alkaline etchant developed by Lawson [13]. The boundaries between the brown and white areas delineated the extent of the austenite formed during holding at the intercritical annealing temperature. In other words, after intercritical annealing, the austenite phase transforms to martensite and new ferrite. The volume fraction of martensite, old and new ferrite is about $0.47,0.37$, and $0.16 \mathrm{vol} \%$, respectively, in the microstructure of water quenched sample.

Figure 3 shows the microstructure of TP steels with employing the austempering treatment at $400{ }^{\circ} \mathrm{C}$ in a salt bath for 20 to $300 \mathrm{~s}$, which creates different combinations of ferrite-bainite-martensite phases. As mentioned earlier, the bainite, martensite, and ferrite appear in blue, brown, and bright, respectively, in the light microscope. Since the intercritical annealing condition is the same for all specimens, so the volume fraction of ferrite is constant for all austempered specimens. The increment in the austempering time increases the bainite volume fraction (blue area) and also decreases volume fraction of martensite (brown area). Table 2 summarises volume fraction of each phase at different austempering times. Additionally, a variation of the volume fraction of constituent phases, including new ferrite, old ferrite, bainite, and martensite versus austempering time is depicted in Fig. 4. It should be mentioned that old ferrite content only depends on intercritical annealing condition, so the volume fraction of old ferrite is the same for all specimens. It is observed that the content of new ferrite in austempered sample (about 24 vol.\%) is higher than that in water quenched sample (about 16 vol.\%). Ardugan [16] reported that cooling rate of media is the main parameter controlling the volume fraction of new ferrite so that increasing cooling rate decreases volume fraction of new ferrite. Actually, since the austenite to ferrite transformation is diffusion controlled, the lower cooling rate provides more time to this transformation, hence the new ferrite content increases. Temperature measurements by a thermocouple, embedded on the surface of samples, recorded cooling rate of 273.5 and $21^{\circ} \mathrm{C} \mathrm{s}^{-1}$ for water and salt batch quenching media, respectively. So the higher volume fraction of new ferrite in austempered sample rather than in water quenched sample is expectable. Figure 4 shows that volume fraction of bainite increases with increasing austempering time, while martensite phase experiences a decreasing trend. Since total volume fraction of hard phases, including bainite and martensite, is 

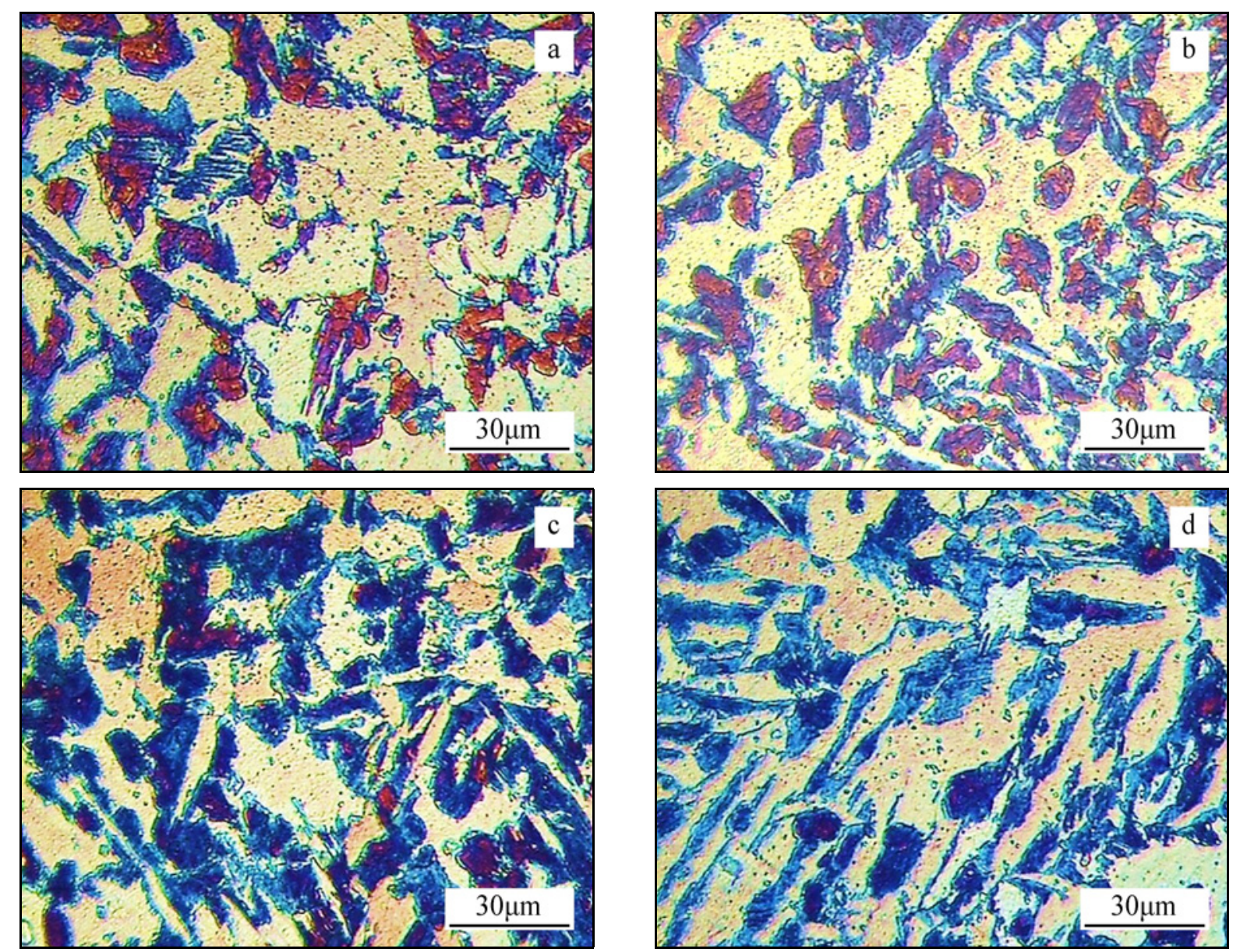

Fig. 3. The microstructure of triple phase steels after austempering at $400^{\circ} \mathrm{C}$ for (a) $20 \mathrm{~s}$, (b) $45 \mathrm{~s}$, (c) $100 \mathrm{~s}$, and (d) $300 \mathrm{~s}$. Light area is ferrite, brown area is martensite, and blue area is bainite.

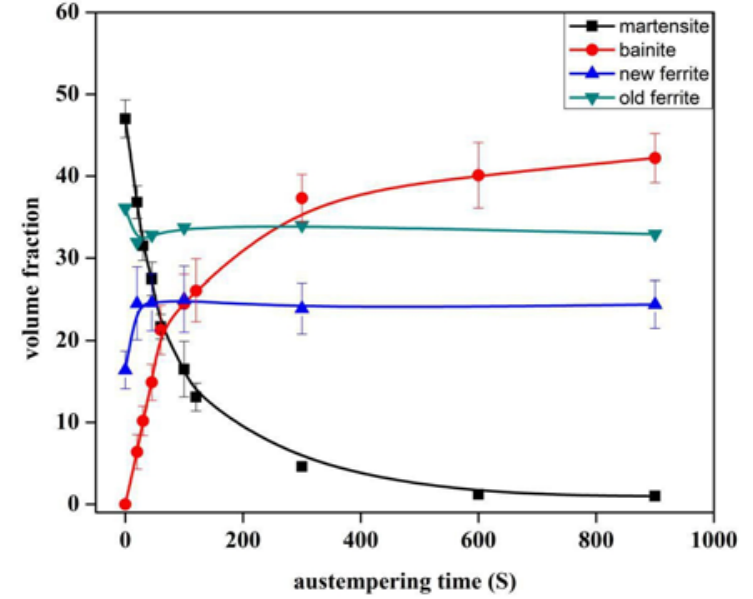

Fig. 4. Variation of the volume fraction of martensite, new ferrite, old ferrite, and bainite with austempering time.

constant, decreasing the amount of martensite in the expense of bainite is logical.

Johnson-Mehl-Avrami-Kolmogorov (JMAK) equation can be utilised to transformation kinetics for isothermal treatments $[17,18]$ :

$$
Y=1-\exp \left(-k t^{n}\right)
$$

where $Y$ is the volume fraction of transformed $\gamma$ within time $t, n$ is the Avrami exponent related to transformation rate, and $k$ is the temperature dependence rate constant. Since the volume fraction of austenite during intercritical annealing cannot reach one, so the $Y$ has to be replaced with $Y=\left(\frac{y}{f_{\max }}\right)$, where $f_{\max }$ is the maximum volume fraction of bainite (about 0.43 when quenched in the salt bath). Equation (3) can be written as:

$$
\ln \left(\ln \left(\frac{1}{1-y}\right)\right)=n \ln (t)+\ln (k) .
$$

Figure 5 shows the variation of $\ln \left(\ln \left(\frac{1}{1-y}\right)\right)$ versus $\ln (t)$. There is a good fit between JMAK equation and experimental results indicated in Fig. 4. The Avrami exponent $(n)$ and the temperature dependence rate constant $(k)$ were determined to be 0.78 and 0.02 , respectively. Actually, the high value of $n$ represents 


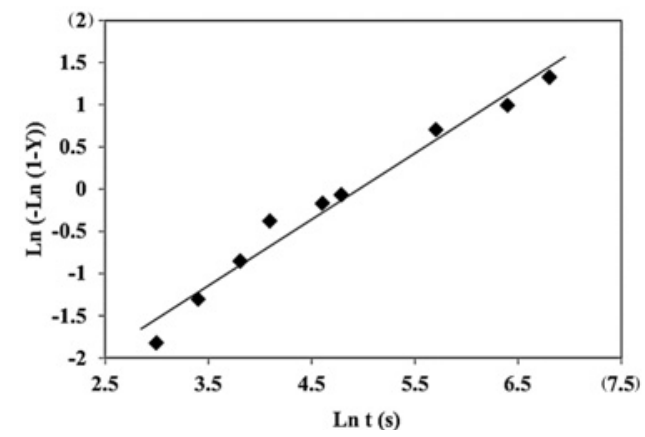

Fig. 5. Variation of $\ln \left(\ln \left(\frac{1}{1-y}\right)\right)$ with $t$, a good fit between JMAK equation and experimental results.

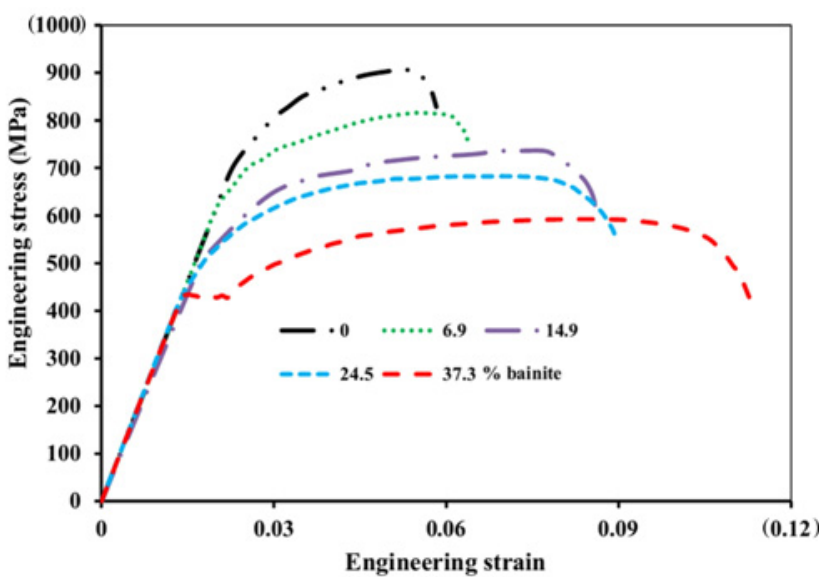

Fig. 6. Engineering stress-strain curves for steels with 0, $6.9,14.9,24.5$, and $37.3 \mathrm{vol} . \%$ bainite.

a high transformation rate for bainitic transformation as indicated in Fig. 4.

\subsection{Mechanical properties}

Figure 6 shows the engineering stress-engineering strain curves of steels with the different volume fraction of bainite. As can be seen, samples with high volume fraction of martensite exhibit a continuous yielding behaviour, whereas discontinuous yielding experiences in high volume fraction of bainite $\left(V_{\mathrm{B}}\right.$ of 37.3 vol.\%). Actually, continuous yielding is related to the density of mobile dislocations in the ferrite phase. Stresses induced by austenite to martensite phase transformation introduce mobile dislocations in ferrite. Accordingly, dislocation sources come into action at low strain during the tensile test, so plastic flow begins simultaneously through the specimen, hence suppressing discontinuous yielding [11]. Since volumetric changes during formation of martensite are higher than those of bainite formation, so decreasing volume fraction of martensite reduces transformation stresses and the number of mobile dislocations intro-

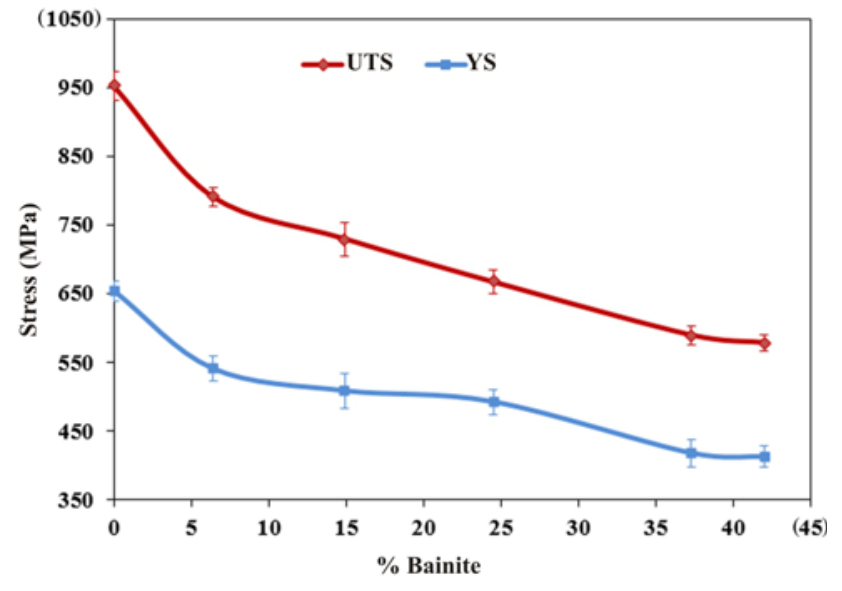

Fig. 7. Variation of yield and ultimate tensile strength with the volume fraction of bainite.

duced to ferrite phase, thereby encourages discontinuous yielding behaviour [6].

Variation of the ultimate tensile strength (UTS) and yield strength (YS) of triple phase steels versus $V_{\mathrm{B}}$ is shown in Fig. 7. UTS and YS experienced a drop with increasing $V_{\mathrm{B}}$. According to the law of mixture (Eq. (5)), the strength of TP steels is exactly related to the volume fraction and also to the strength of constituent phases:

$$
\sigma_{\text {total }}=\sigma_{\mathrm{F}} V_{\mathrm{F}}+\sigma_{\mathrm{M}} V_{\mathrm{M}}+\sigma_{\mathrm{B}} V_{\mathrm{B}}
$$

where $\sigma_{\text {total }}$ is the strength of the steel and $\sigma_{\mathrm{F}}, \sigma_{\mathrm{M}}$, and $\sigma_{\mathrm{B}}$ are the strength of ferrite, martensite, and bainite phase, respectively. As mentioned earlier, the volume fraction of ferrite $\left(V_{\mathrm{F}}\right)$ is constant, while $V_{\mathrm{M}}$ and $V_{\mathrm{B}}$ are changed with increasing the austempering time. Actually, when $V_{\mathrm{F}}$ is constant, a variation of $V_{\mathrm{M}}$ has a dominant role in mechanical properties of TP steels. Since the strength of martensite $\left(\sigma_{\mathrm{M}}\right)$ is higher than that of bainite $\left(\sigma_{\mathrm{B}}\right)$, so by increasing the $V_{\mathrm{B}}$, UTS and YS decrease.

It should also be mentioned, although the volume fraction of ferrite $\left(V_{\mathrm{F}}\right)$ is constant during austempering treatment, but martensitic transformation stresses are greater than bainitic transformation stresses, thereby more stresses and dislocations within the ferrite grains are introduced. Accordingly, the strength of ferrite $\left(\sigma_{\mathrm{F}}\right)$ decreases with increasing bainite volume fraction, which can have an effect on the strength of steel. It is noticeable that by the formation of bainite from the austenite during austempering treatment, the carbon content of remaining austenite increases. So, with increasing the carbon content of austenite, the strength of martensite which forms from the austenite, increases. It means that $\sigma_{\mathrm{M}}$ in Eq. (5) increases with increasing austempering time. More attention to Fig. 7 reveals a drastic difference between 


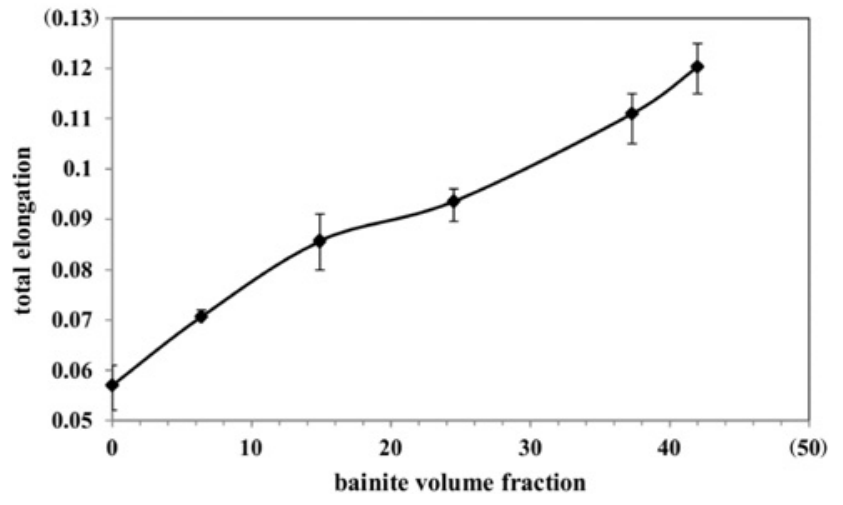

Fig. 8. Variation of ductility, in terms of uniform elongation, with the volume fraction of bainite.

the strength of water quenched sample $\left(V_{\mathrm{B}}=0\right)$ and a sample containing low volume fraction of bainite $(6.9 \mathrm{vol} . \%)$. This difference is attributed to the formation of new ferrite phase during a lower cooling rate of salt bath quenching, so the total volume fraction of hard phases $\left(V_{\mathrm{B}}+V_{\mathrm{M}}\right)$ and also the strength decrease. So at the same volume fraction of ferrite, the strength of ferrite-martensite DP is higher than that of TP and ferrite-bainite DP steels.

To investigate the ductility, the total elongation of samples was calculated. Figure 8 depicts the variation of total elongation with bainite volume fraction. It is observed that elongation increases with an increment of the volume fraction of bainite. Since the ductility of bainite is higher than that of martensite, increasing elongation with decreasing martensite volume fraction is expectable [5]. As mentioned earlier, stresses induced by austenite to bainite transformation are lower than by martensite formation that results in a reduction of dislocation density introduced to ferrite phase, thereby causes the increment of ductility.

\subsection{Work hardening behaviour}

Figure 9 shows $\ln (\sigma)-\ln (\varepsilon)$ plots, which were obtained using the Holloman's equation, $\sigma=\left(k \varepsilon^{n}\right)$, for steels with the different volume fraction of bainite. It is observed that steels with $0,6.9$, and 37.3 vol. $\%$ of bainite obey the two-stage work hardening mechanism, while in steels with 14.9 and 24.5 vol. $\%$ of bainite three stages of work hardening can be considered. Two-stage work hardening behaviour has also been reported by other researchers $[19,20]$. The first stage is associated with plastic deformation of the ferrite matrix, and at the second stage, both of ferrite and hard phase (bainite or martensite) deform plastically. Since in the steel with 6.9 vol.\% of bainite, the amount of bainite phase is not enough to cause separate work hardening stage, so only two-stage work hardening mechanism is observed. In samples with 14.9 and 24.5 vol.\% bainite, the content of both bainite and martensite phase is high enough to have an important effect on work hardening steps, so three different work hardening stages can be considered. At the first stage, only soft ferrite phase deforms plastically while hard phases, bainite and martensite, deform elastically. With increasing stress, plastic deformation of bainite also occurs as well as that of ferrite at the second stage. Since the martensite phase is stronger than ferrite and bainite, its plastic deformation begins at the final stage of work hardening where the third stage of work hardening takes place. In the sample with 37.3 vol. $\%$ bainite, the fraction of martensite phase is low (4.6 vol.\%) to have an important effect on work hardening steps, so just two different work hardening stages are observed.

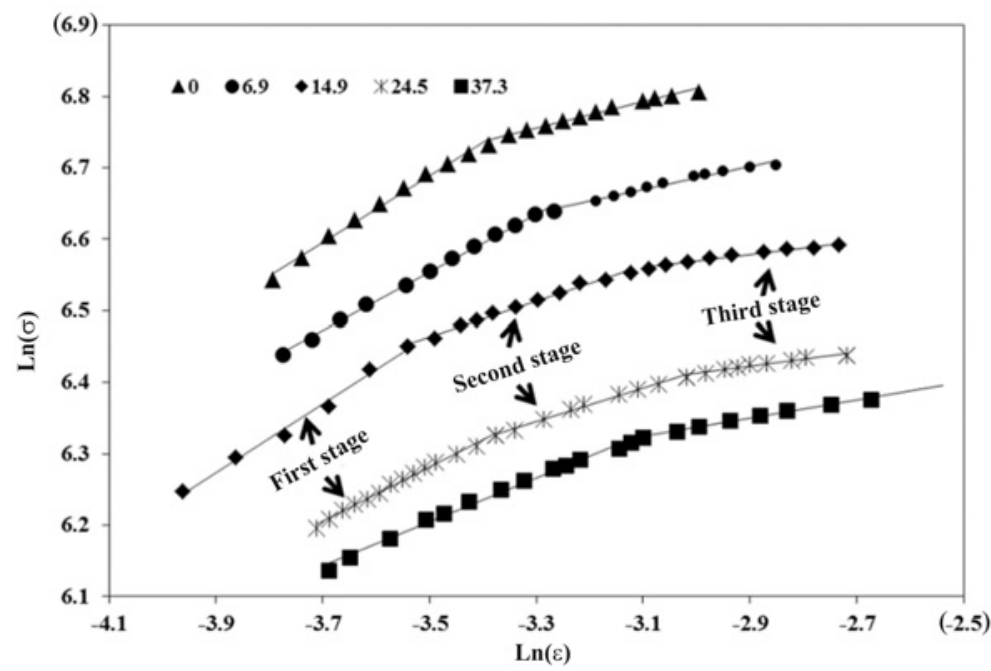

Fig. 9. Plots of $\ln (\sigma)-\ln (\varepsilon)$ for TP steels with different VB. 

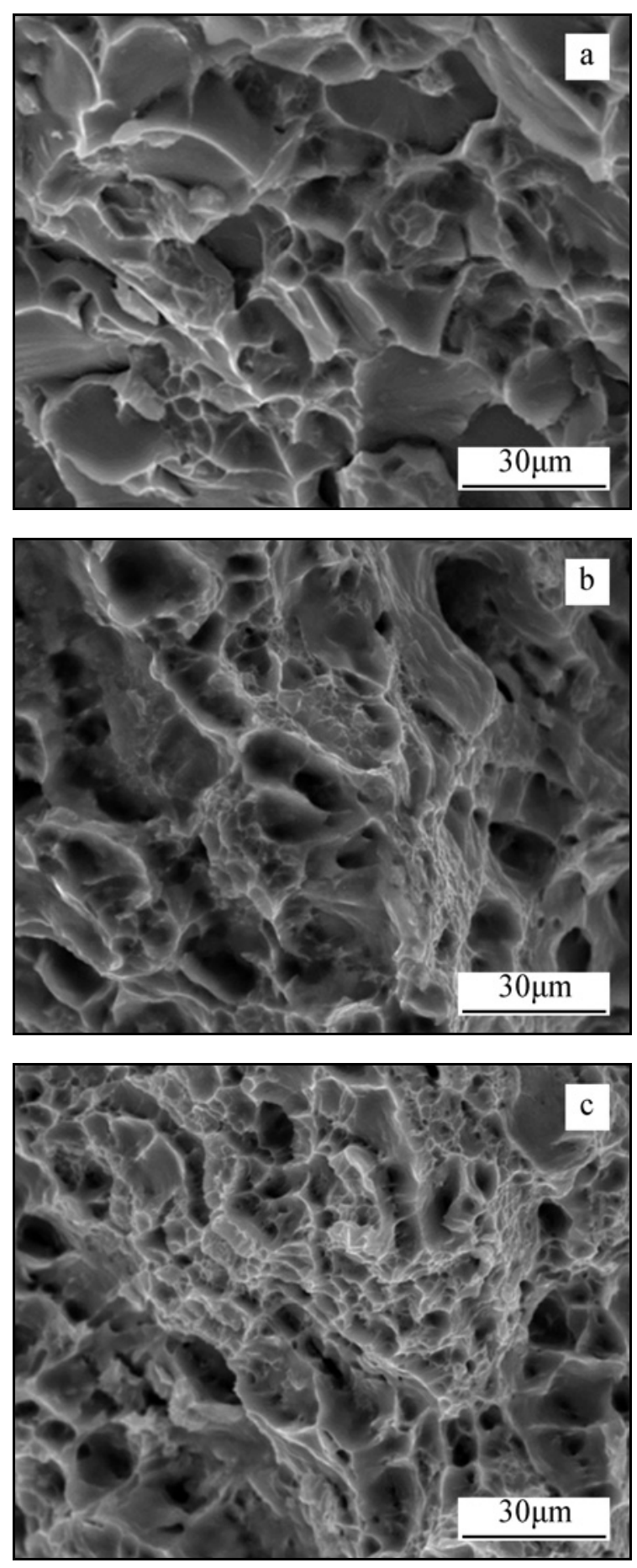

Fig. 10. SEM micrographs of fracture surfaces for tensiletest specimens with (a) 0, (b) 14.9, and (c) 43 vol.\% bainite.

\subsection{Fractography}

Fracture surfaces of three tensile test specimens with $0,14.9$, and 42.2 vol.\% bainite are illustrated in Fig. 10. Figure 10a, which corresponds to 0 vol. $\%$ bainite, reveals brittle regions indicating a cleavage frac- ture that has also been reported for DP steels by some researchers [21-23]. Fracture surface of specimen with 14.9 vol.\% bainite consists of both brittle and ductile regions. Many small and shallow dimples can be seen near brittle regions. Figure 10c, ferrite- 42.2 vol.\% bainite microstructure, shows a surface which is fully covered by large and deep dimples, indicating a ductile fracture. Actually larger and deeper dimples, relative to small and shallow dimples, reveal that microvoids have been joined together at higher strains, indicating to higher toughness [9]. Localised strains due to the formation of martensite are higher than those of bainite formation, thereby higher density of dislocation will be introduced into ferrite especially at the interphase boundary. So with decreasing volume fraction of martensite, the density of dislocation at interphase boundaries decreases thus supersedes crack propagation at these regions and increases ductility $[9]$.

Additionally, the presence of interconnected martensite islands (as obviously can be seen in Fig. 2a) can lead to brittle fracture of DP steels because of constraining plastic flow in the ferrite [8]. Formation of bainite phase as well as the higher volume fraction of the new ferrite (about 8 vol.\%) in austempered samples interrupts the connectivity of martensite phase and results in increasing ductility.

\section{Conclusions}

In the present study an austempering treatment was carried out on plain carbon steel at $400{ }^{\circ} \mathrm{C}$ for different times, then the effect of bainite volume fraction on tensile properties and work hardening behaviour was investigated, and results lead to the following conclusions:

1. Changing quenching media from water $\left(273.5^{\circ} \mathrm{C} \mathrm{s}^{-1}\right)$ to salt bath $\left(21^{\circ} \mathrm{C} \mathrm{s}^{-1}\right)$ increased the volume fraction of new ferrite from 0.16 to 0.24 vol. $\%$.

2. The kinetics of bainitic transformation obeys JMAK equation with $n=0.78$ and $k=0.02$.

3. Increasing bainite volume fraction from 0 to 0.42 decreased yield strength from 654 to $412 \mathrm{MPa}$ while total elongation increased from 5.7 to 12 vol.\%.

4. Dual ferrite-martensite and also triple ferritebainite-martensite microstructure with 6.9 and 37.3 bainite vol.\% showed two-stage work hardening behaviour while triple phase steels with 14.9 and 24.5 bainite vol.\% obeyed three-stage work hardening.

\section{References}

[1] Gündüz, S.: Mater. Sci. Eng. A, 486, 2008, p. 63. $\underline{\text { doi:10.1016/j.msea.2007.08.056 }}$ 
[2] Mejía, I., Bedolla-Jacuinde, A., Maldonado, C., Cabrera, J. M.: Mater. Sci. Eng. A, 528, 2011, p. 4468. doi:10.1016/j.msea.2011.02.040

[3] Asadi Asadabad, M., Goodarzi, M., Kheirandish, Sh.: ISIJ Int., 48, 2008, p. 1251. doi:10.2355/isijinternational.48.1251

[4] Hernandez, V. B., Nayak, S., Zhou, Y.: Metall. Mater. Trans. A, 42, 2011, p. 3115. doi:10.1007/s11661-011-0739-3

[5] Bhadeshia, H.: IOM Communications Ltd., London, 2001, p. 237.

[6] Saeidi, N., Ekrami, A.: Mater. Sci. Eng. A, 523, 2009, p. 125. doi:10.1016/j.msea.2009.06.057

[7] Podder, A. S., Bhattacharjee, D., Ray, R.: ISIJ Int., 47, 2007, p. 1058. doi:10.2355/isijinternational.47.1058

[8] Lai, Q., Bouaziz, O., Gouné, M., Brassart, L., Verdier, M., Parry, G., Perlade, A., Bréchet, Y., Pardoen, T.: Mater. Sci. Eng. A, 646, 2015, p. 322. doi:10.1016/j.msea.2015.08.073

[9] Zare, A., Ekrami, A.: Mater. Sci. Eng. A, 530, 2011, p. 440. doi:10.1016/i.msea.2011.09.108

[10] Abdollah-Zadeh, A., Salemi, A., Assadi, H.: Mater. Sci. Eng. A, 483-484, 2008, p. 325. doi:10.1016/j.msea.2006.12.179

[11] Movahed, P., Kolahgar, S., Marashi, S. P. H., Pouranvari, M., Parvin, N.: Mater. Sci. Eng. A, 518, 2009, p. 1. doi:10.1016/j.msea.2009.05.046

[12] George, F. V. V.: ASM Handbook: Metallography and Microstructures. Materials Park, ASM International 2004.
[13] Lawson, R. D., Matlock, D. K., Krauss, G.: Metallography, 13,1980 , p. 71. doi: 10.1016/0026-0800(80)90023-3

[14] ASTM E8: Standard Test Methods for Tension Testing of Metallic Materials. Volume 3. 2009.

[15] Jeong, W. C., Kim, C. H.: Scripta Metall. Mater., 19, 1985, p. 37. doi:10.1016/0036-9748(85)90261-3

[16] Erdogan, M.: Scripta Mater., 48, 2003, p. 501. doi:10.1016/S1359-6462(02)00500-6

[17] Bhadeshia, H. K. D. H.: Bainite in Steels. Transformations, Microstructure and Properties. London, IOM Communications, Ltd. 2001.

[18] Bhadeshia, H. K. D. H.: Mater. Sci. Eng. A, 273-275, 1999, p. 58. doi:10.1016/S0921-5093(99)00289-0

[19] Akbarpour, M. R., Ekrami, A.: Mater. Sci. Eng. A, 475, 2008, p. 293. doi:10.1016/i.msea.2007.04.099

[20] Zare, A., Ekrami, A.: Mater. Sci. Eng. A, 528, 2011, p. 4422. doi:10.1016/i.msea.2011.02.021

[21] Kim, N. J., Thomas, G.: Metall. Trans. A, 12, 1981, p. 483. doi:10.1007/BF02648546

[22] Uggowitzer. P., Stüwe, H. P.: Mater. Sci. Eng. A, 55, 1982, p. 181. doi:10.1016/0025-5416(82)90131-8

[23] Kunio, T., Shimizu, M. K., Yamada, K., Suzuki, H.: Eng. Fract. Mech., 7, 1975, p. 411. doi:10.1016/0013-7944(75)90041-7 